\title{
Encephalitis, severe seizures, and multifocal brain lesions
}

Recognizing autoimmunity to the $\mathrm{GABA}_{\mathrm{A}}$ receptor

Eric Lancaster, MD, PhD

Neurol Neuroimmunol Neuroinflamm 2019;6:e554. doi:10.1212/NXI.0000000000000554

In this issue of $N 2$, the paper by O'Connor et al. ${ }^{1}$ reports the clinical, immunologic, and radiographic features of a series of patients with anti- $\gamma$-aminobutyric acid type $A\left(G A B A_{A}\right)$ receptor encephalitis. Anti-GABA $A_{A}$ receptor encephalitis is characterized by cognitive disruption, severe seizures, and characteristic brain lesions. ${ }^{2}$ The disease affects a very broad age range and both sexes. In the current study, as in prior reports, most patients responded favorably to immune therapy, although the optimal approach is still not clear. The series does provide a cautionary note regarding a patient with delayed diagnosis who had poor outcome. The present report further confirms the risk of thymoma, among other malignancies, although cases occurring after herpes virus infection have also been reported. ${ }^{3}$

The $\mathrm{GABA}_{\mathrm{A}}$ receptor is a pentameric chloride channel and the primary rapid inhibitory system in the adult brain. ${ }^{4} \mathrm{GABA}_{\mathrm{A}}$ receptors are incredibly diverse, being comprised of many possible combinations of $6 \alpha$ subunits, $3 \beta$ subunits, $3 \gamma$ subunits and $4 \delta$ subunits. The current paper and prior reports have reported antibodies targeting receptors containing $\alpha 1$ and $\beta 3$ subunits. The antibodies therefore recognize only a subset of $\mathrm{GABA}_{\mathrm{A}}$ receptors, although these isoforms are widely distributed in the brain. ${ }^{5}$ It is unknown whether other patients may have antibodies to other isoforms of the $\mathrm{GABA}_{\mathrm{A}}$ receptor, or what factors may make these particular subunits particularly immunogenic.

The antibodies decrease surface levels of the target receptor on cultured neurons and are very likely directly pathogenic. ${ }^{2}$ Severe seizures, particularly epilepsia partialis continua or status epilepticus, are common. $\mathrm{GABA}_{\mathrm{A}}$ receptor antibodies may therefore be a potential etiology of new onset refractory status epilepticus and should be considered among the other potential autoimmune causes such as $\mathrm{GABA}_{\mathrm{B}}$ receptor antibodies, NMDA receptor antibodies, etc. ${ }^{6}$

The current paper ${ }^{1}$ shows excellent examples of the striking and dynamic brain lesions of the disorder, which are readily apparent on T2-weighted MRI studies, and affect both gray and white matter. Some patients may show large areas of cortical edema. Interestingly, the brain lesions tend to respond well to immune therapy, vanishing completely over weeks to months, and leaving little or no residual findings after treatment. Anti-GABA $A_{A}$ receptor encephalitis therefore enters into the differential diagnosis of MS and acute disseminated encephalomyelitis. In their most dramatic manifestations, these changes are, if not pathognomonic, at least highly suggestive of the disorder. It is unclear whether $\mathrm{GABA}_{\mathrm{A}}$ receptor antibodies themselves cause the brain lesions, although the rich expression of $\mathrm{GABA}_{\mathrm{A}}$ receptors on astrocytes may be involved. It is an open question whether other patients with the antibodies may have atypical presentations and thus been under-represented in the published case series.

\author{
Correspondence \\ Dr. Lancaster \\ Eric.lancaster@uphs.upenn.edu
}

\section{RELATED ARTICLE}

$\mathrm{GABA}_{\mathrm{A}}$ receptor autoimmunity: A multicenter experience

Page e552 
The current paper is a cooperative project involving the Mayo and Oxford groups, as well as researchers at other institutions, and is in agreement with the original work by Dr. Dalmau's group in Barcelona. The confirmation of the nature of the antibodies and associated clinical phenotypes by multiple research groups should be reassuring to physicians who are familiar with the problem of irreproducible or never-replicated autoantibody findings in neurology. As autoantibodies in neurology continue to be proposed, an organized multicenter program may be necessary someday to systematically confirm or refute the proposed autoimmune markers.

In summary, anti-GABA $\mathrm{A}_{\mathrm{A}}$ receptor encephalitis is a distinct autoimmune disease characterized by encephalitis, severe seizures, and distinctive brain lesions. It may enter into the differential diagnosis of diverse disorders and can be reliably diagnosed by a cell-based antibody test. Prompt diagnosis and treatment generally results in recovery.

\section{Study funding}

No targeted funding reported.

\section{Disclosure}

E. Lancaster is a co-inventor on a patent related to CAR-T therapy for cancer, consulted for Merck, Janssen, received research support from Grifols, NINDS, and received a fee for expert review of cases for Federal Vaccine Injury Compensation. Disclosures available: Neurology.org/NN.

\section{Publication history}

Received by Neurology: Neuroimmunology \& Neuroinflammation February 14, 2019. Accepted in final form February 19, 2019.

\section{References}

1. O'Connor K, Waters $\mathrm{P}$, Komorowski L, et al. $\mathrm{GABA}_{\mathrm{A}}$ receptor autoimmunity: A multicenter experience. Neurol Neuroimmunol Neuroinflamm 2019;6:e552. doi:10.1212/NXI.0000000000000552.

2. Petit-Pedrol M, Armangue T, Peng X, et al. Encephalitis with refractory seizures, status epilepticus, and antibodies to the GABAA receptor: a case series, characterisation of the antigen, and analysis of the effects of antibodies. Lancet Neurol 2014;13:276-286.

3. Spatola M, Petit-Pedrol M, Simabukuro MM, et al. Investigations in GABAA receptor antibody-associated encephalitis. Neurology 2017;88:1012-1020.

4. Sieghart W. Structure, pharmacology, and function of GABAA receptor subtypes. Adv Pharmacol 2006;54:231-263.

5. Nikolaus M, Kreye J, Turko P, Vida I, Knierim E, Pruss H. CSF reactivity in GABAA receptor antibody encephalitis - immunocytochemical distribution in the murine brain. Brain Res 2019;1704:249-256.

6. Gaspard N, Foreman BP, Alvarez V, et al. New-onset refractory status epilepticus: etiology, clinical features, and outcome. Neurology 2015;85:1604-1613. 


\title{
Neurology $^{\odot}$ \\ Neuroimmunology \& Neuroinflammation
}

\author{
Encephalitis, severe seizures, and multifocal brain lesions: Recognizing autoimmunity \\ to the GABAA receptor \\ Eric Lancaster \\ Neurol Neuroimmunol Neuroinflamm 2019;6; \\ DOI 10.1212/NXI.0000000000000554
}

This information is current as of April 4, 2019

\section{Updated Information \& \\ Services}

References

Citations

Subspecialty Collections

Permissions \& Licensing

Reprints including high resolution figures, can be found at:

http://nn.neurology.org/content/6/3/e554.full.html

This article cites 6 articles, 1 of which you can access for free at: http://nn.neurology.org/content/6/3/e554.full.html\#\#ref-list-1

This article has been cited by 1 HighWire-hosted articles: http://nn.neurology.org/content/6/3/e554.full.html\#\#otherarticles

This article, along with others on similar topics, appears in the following collection(s):

Autoimmune diseases

http://nn.neurology.org//cgi/collection/autoimmune_diseases

MRI

http://nn.neurology.org//cgi/collection/mri

Partial seizures

http://nn.neurology.org//cgi/collection/partial_seizures

Information about reproducing this article in parts (figures,tables) or in its entirety can be found online at:

http://nn.neurology.org/misc/about.xhtml\#permissions

Information about ordering reprints can be found online:

http://nn.neurology.org/misc/addir.xhtml\#reprintsus

Neurol Neuroimmunol Neuroinflamm is an official journal of the American Academy of Neurology.

Published since April 2014, it is an open-access, online-only, continuous publication journal. Copyright

Copyright $\odot 2019$ The Author(s). Published by Wolters Kluwer Health, Inc. on behalf of the American

Academy of Neurology.. All rights reserved. Online ISSN: 2332-7812.

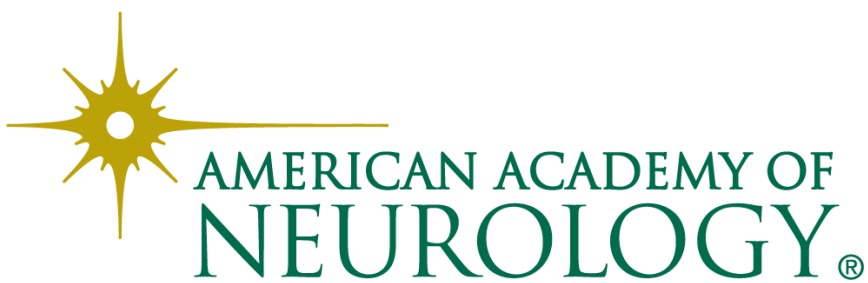

